MICHAL KSIAŻKIEWICZ

PIOTR PLEWIŃSKI

SANDRA RYCHEL

MAGDALENA TOMASZEWSKA

ANETA SAWIKOWSKA

WOJCIECH BIELSKI

BARBARA NAGANOWSKA

BOGDAN WOLKO

Instytut Genetyki Roślin Polskiej Akademii Nauk w Poznaniu

Kierownik Tematu: dr Michał Książkiewicz Instytut Genetyki Roślin Polskiej Akademii Nauk

ul. Strzeszyńska 34, 60-479 Poznań, tel. 61 6550268, e-mail:mksi@igr.poznan.pl

Prace zostaly wykonane $w$ ramach badań podstawowych na rzecz postęu biologicznego $w$ produkcji roślinnej na podstawie decyzji Ministra Rolnictwa i Rozwoju Wsi nr HOR.hn.802.18.2018. Zadanie 39.

\title{
Cecha wczesności kwitnienia u łubinu białego i łubinu żółtego — podstawy genetyczne i molekularne
}

\author{
Early flowering traits of white lupin and yellow lupin — genetic and molecular \\ backgrounds \\ Słowa kluczowe: termin kwitnienia, wernalizacja, phenotypowanie, mapowanie genetyczne, \\ sekwencjonowanie DNA, sekwencjonowanie RNA

\section{TEMAT BADAWCZY 1}

Realizację zadania podzielono na cztery tematy badawcze.

Celem tematu badawczego 1 było otrzymanie linii pokolenia F5 z krzyżówek łubinu żółtego $\uparrow$ PRH444/14× $\overbrace{}^{\lambda}$ Parys i $\uparrow$ Parys $\times{ }^{\lambda}$ PRH444/14 oraz poznanie wymagań wernalizacyjnych wybranych linii z kolekcji łubinu białego.

W stacji Hodowli Roślin Smolice, Oddział w Przebędowie, wysiano nasiona z pokolenia F4: + PRH444/14× ${ }^{\wedge}$ Parys i OParys $\times{ }^{\Uparrow} \mathrm{PRH} 444 / 14$. Uzyskano plon z 200 linii $\mathrm{z}$ każdej kombinacji krzyżówkowej w ilości wystarczającej ( $\mathrm{z}$ rezerwą na ewentualne powtórzenia) do kontynuacji prac w następnych latach.

Doświadczenie ukierunkowane na ocenę terminu kwitnienia łubinu białego założono w warunkach szklarniowych (z wernalizacją i bez wernalizacji). Badano 110 linii z kolekcji (Poznańska Hodowla Roślin, Oddział Wiatrowo) oraz 2 linie rodzicielskie populacji mapującej (Kiev Mutant i P27174). Doświadczenie wykazało, że w kolekcji 
występuje znaczna zmienność zarówno terminu wiązania pąków, kwitnienia, dojrzewania strąków, jak i odpowiedzi w zakresie tych trzech cech na wernalizację. Dla linii wernalizowanych średni termin od wysiania do wiązania pąków zawierał się w zakresie 26-50 dni, zaś nie poddanych wernalizacji: 31-76 dni. Srednia liczba dni do inicjacji kwitnienia wynosiła 33-61 dni dla roślin wernalizowanych (w 2015 roku: 38-77 dni) i 37-80 dni dla niewernalizowanych (w 2015 roku: 43-87 dni). Zaobserwowano duże zróżnicowanie odpowiedzi na wernalizację — od przyspieszenia kwitnienia o 34 dni do całkowitej termoneutralności. Są to wyniki podobne do tych uzyskanych w 2015 roku (zakres od -36 do +2 dni). Linie wczesne po wernalizacji przyspieszały termin kwitnienia o 1-6 dni. Największe zróżnicowanie tej cechy występowało w liniach późnych (przyspieszenie o 10-32 dni). Wpływ wernalizacji na termin dojrzewania strąków był statystycznie istotny dla linii pośrednich i późnych — średnie przyspieszenie terminu dojrzewania wynosiło około 7 dni.

\section{Wnioski}

- Cecha wczesności kwitnienia łubinu białego jest cechą ilościową, warunkowaną przez kilka niesprzężonych ze sobą genów.

- Linie rodzicielskie populacji mapującej łubinu białego istotnie różnią się terminem kwitnienia i wymaganiami wernalizacyjnymi.

\section{TEMAT BADAWCZY 2}

Celem tematu badawczego 2 była identyfikacja miejsc polimorficznych różnicujących linie rodzicielskie populacji mapującej oraz wybrane linie wczesne i późne łubinu żółtego w obrębie sekwencji homologów znanych genów uczestniczących w procesie indukcji kwitnienia i opracowanie na tej podstawie markerów molekularnych. Zestaw sekwencji obejmował następujące geny:

- integratory szlaków indukcji kwitnienia: FLOWERING LOCUS T (FTala, FTalb, FTc1, FTc2), UNIFOLIATA (UNIa, UNIb);

— geny ze szlaku wernalizacyjnego: FRIGIDA, VERNALIZATION INDEPENDENCE 3;

- geny ze szlaku autonomicznego: FLOWERING LOCUS D, FLOWERING PROTEIN A (FPAa, FPAb), FY, SQUAMOSA6;

- gen inicjujący kwitnienie w odpowiedzi na stresy abiotyczne: BROTHER OF FT AND TFL1;

- geny indukujące kwitnienie w zależności od temperatury TERMINAL FLOWER 1 (TFL1a, TFL1b), PHYTOCHROME INTERACTING FACTOR 4;

- gen ze szlaku fotoperiodycznego: CYCLIC DOF FACTOR 3;

— gen regulujący dojrzewanie nasion: MOTHER OF FT AND TFL1;

- geny indukcji kwitnienia w ramach rytmu dobowego: EARLY FLOWERING 1, EARLY FLOWERING 3, EARLY FLOWERING 4, SKI-INTERACTING PROTEIN 1;

— gen zlokalizowany w obrębie jednego z loci QTL wczesności kwitnienia łubinu białego: DNAJ10.

Loci polimorfizmu pojedynczego nukleotydu (SNP) pomiędzy liniami rodzicielskimi polskiej populacji mapującej (PRH444/14 $\times$ Parys) zidentyfikowano dla 8 genów, zaś 
pomiędzy liniami rodzicielskimi australijskiej populacji mapującej (Wodjil $\times$ P28213) dla 19 genów. Polimorfizm insercji/delecji zidentyfikowano dla 3 genów (PRH444/14 $\times$ Parys) oraz dla 10 genów (Wodjil $\times$ P28213). Zaprojektowano 2 markery typu PCR, 6 CAPS i 2 dCAPS (PRH444/14×Parys) oraz 3 markery typu PCR, 19 CAPS i 1 dCAPS (Wodjil $\times$ P28213).

\section{Wnioski}

— Obserwowany poziom polimorfizmu między liniami wczesnymi a późnymi łubinu żółtego jest zbliżony do tego, który występuje u łubinu wąskolistnego i białego.

- Zaprojektowane markery polimorficzne zakotwiczone w sekwencjach genów związanych $\mathrm{z}$ procesem indukcji kwitnienia będą mogły być wykorzystane do mapowania genetycznego w obrębie dwóch populacji mapujących łubinu żółtego — polskiej i australijskiej.

\section{TEMAT BADAWCZY 3}

Celem tematu badawczego 3 było poznanie profilu ekspresji i sekwencji genów kwitnienia dla linii rodzicielskich populacji mapującej oraz wybranych linii wczesnych i późnych łubinu żółtego metodą sekwencjonowania nowej generacji.

Materiałem badawczym było 5 linii wybranych na podstawie obserwacji fenotypowych, polimorfizmu markerów DNA oraz danych literaturowych: Wodjil wczesna, termoneutralna, z Australii; P28213 - późna, wymagająca wernalizacji, z Portugalii; Population Sewilla-4 — późna, wymagająca wernalizacji, z Hiszpanii; Parys — pośrednia, z Polski; PRH 444/14 — bardzo wczesna, termoneutralna, z Polski.

Doświadczenie zostało założone w warunkach kontrolowanych w Centrum Uprawy Roślin IGR PAN (z wernalizacją i bez wernalizacji): temperatura $18^{\circ} \mathrm{C}$ (noc) $/ 22^{\circ} \mathrm{C}$ (dzień), fotoperiod 16 godzin, wilgotność $50-70 \%$. Do izolacji RNA i sekwencjonowania RNA pobrano tkankę liści 28 i 35 dni po wysianiu nasion.

Analiza różnicowa ekspresji genów wykazała, że większość homologów znanych genów kwitnienia była aktywna ekspresyjnie we wszystkich badanych wariantach/genotypach. Dla niektórych genów zaobserwowano zróżnicowanie poziomu ekspresji dla poszczególnych kopii w zależności od terminu, genotypu lub zastosowanej wernalizacji. Określono geny kandydujące, które mogą odpowiadać za cechę wczesności kwitnienia u linii termoneutralnych.

\section{Wnioski}

— Niektóre homologi genów indukcji kwitnienia u łubinu żółtego uległy duplikacji i subfunkcjonalizacji (dywergencji).

- Zidentyfikowano dwa geny kandydujące, które prawdopodobnie odpowiadają za zniesienie wymagań wernalizacyjnych i wczesność kwitnienia linii PRH444/14. 


\section{TEMAT BADAWCZY 4}

Celem tematu badawczego 4 było opracowanie markerów do rutynowego genotypowania głównych QTL cechy wczesności kwitnienia łubinu białego i określenie za ich pomocą profilu tych QTL w światowej kolekcji tego gatunku.

Podczas realizacji tego zadania w latach 2016-2018 określono 5 loci QTL wczesności kwitnienia $(1 N-5 N)$, które były wspólne dla wszystkich doświadczeń, w których nasiona nie były wernalizowane (doświadczenia polowe w latach 2004, 2005, 2015 i doświadczenie szklarniowe w 2016). Do genotypowania wybrano 10 markerów, po 2 na każde locus QTL wczesności kwitnienia. Użycie markerów zakotwiczonych w genach kandydujących pozwoliło na analizę frekwencji alleli odpowiadających za późne kwitnienie linii P27174 w kolekcji i częstości rekombinacji wokół tych loci. Zidentyfikowano, że allel „późny” $4 N$ zawiera jedna linia, allel „późny” $1 N$ zawierają dwie linie, allel „późny” genu $2 N$ posiadają 4 linie, allel „późny” genu $5 N$ ma 18 linii, zaś allel późny genu $3 N-33$ linie. Zaobserwowano szybki spadek współczynnika nierównowagi sprzężeń w miarę oddalania się od genów kandydujących za wyjątkiem locus $5 N$.

\section{Wnioski}

- Uzyskany zestaw markerów pozwala na wiarygodną identyfikację alleli dla wszystkich pięciu głównych loci wczesności kwitnienia łubinu białego.

- Wprowadzenie odporności na antraknozę $\mathrm{z}$ dzikich linii etiopskich do linii udomowionych jest możliwe jedynie przy użyciu linii wczesnych i termoneutralnych niespokrewnionych z linią Kiev Mutant.

— W kolekcji znajdują się co najmniej cztery linie, które mogą być użyte jako donory wczesności kwitnienia w krzyżowaniach z komponentami z Etiopii. 